\title{
УДК 81.2
}

\section{КУЛЬТУРА УРАЛЬСКИХ (ЯИЦКИХ) КАЗАКОВ-СТАРООБРЯДЦЕВ СКВОЗЬ ПРИЗМУ ЯЗЫКА (НА МАТЕРИАЛЕ УРАЛЬСКИХ ГОВОРОВ)}

\author{
Пирманова Н.И.
}

ФГБОУ ВПО «Оренбургский государственный педагогический университет имени В.П. Чкалова», Оренбург, Россия (460050, Оренбург, ул. Пролетарская, 308-217), e-mail: nazira056@mail.ru

В статье рассматривается отражение культурных ценностей уральских (яицких) казаков-старообрядцев в диалектной лексике, зафиксированной в словаре уральских говоров Нестора Михайловича Малечи. Языковые единицы, характеризующие особенности быта, вероисповедания уральских (яицких) казаков, анализируются с целью выявления этнолингвокультурологической информации. Диалектизмы, представленные в словаре уральских говоров, исследуются автором статьи - уроженкой Первомайского района Оренбургской области, - территории, где данные говоры имели распространение. Объектом данной статьи являются слова, характеризующие чистоту веры казаков-старообрядцев, традиции, обычаи, нравы, отношение к тем реалиям, которые входили в их жизнь в связи с историческими событиями. Уральское казачество благодаря особым социокультурным условиям своего зарождения и развития всегда старалось уберечь родной язык и православную веру. Особое внимание автор акцентирует на специфике быта, культуры, идеологии, этнопсихического уклада, поведенческих стереотипов, фольклора уральских (яицких) казаков-старообрядцев.

Ключевые слова: уральские говоры, диалектная лексика, казаки-старообрядцы, культура уральских (яицких) казаков.

\section{THE CULTURE OF THE URAL (YAITSKIY) COSSAKS - OLD-BELIEVERS THROUGH THE LANGUAGE (BASED ON THE URAL DIALECTS)}

\section{Pirmanova N.I.}

Orenburg State Pedagogical University,e-mail: nazira056@mail.ru

The article is about the reflection of cultural values of the Ural (Yaitskiy) Cossacks - old - believers in dialects, registered in the dictionary of Ural dialects by Nestor Mikhailovich Malech. Language units, characterizing the peculiarities of life, religion of the Ural Cossacks, are analyzed in order to discover ethnolinguocultural information. Dialect words, recorded in the dictionary of Ural dialects, are examined by the author of the article who was born in Pervomajskiy area of Orenburg region, which is the territory where these dialects were spread. The words, characterizing the purity of belief of old-believers, traditions, customs, attitude to those things, which came into their life due to the historical events, are the object of this article. Thanks to special sociocultural conditions of their origin and development, the Ural Cossacks always tried to save their native language and the Orthodox belief. According to the author, the special attention should be paid to the peculiar life, behavior, folklore of Ural (Yaitskiy) Cossaks-old-believers.

Keywords: Ural dialects, dialect words, Cossacks-old-belivers, culture of Ural (Yaitskiy) Cossacks.

Предметом нашего исследования является анализ лексики, отражающей культуру уральских (яицких) казаков-старообрядцев, зафиксированной в словаре говоров уральских (яицких) казаков Нестора Михайловича Малечи. Мы исследуем лексические единицы, характеризующие религиозные устои, традиции, привычки, специфику уклада жизни староверов - уральских (яицких) казаков [9].

Во Введении к словарю Н. М. Малечи поясняется, что уральские (яицкие) казаки, лексика которых представлена в словаре, населяют правобережные районы Гурьевской и Уральской областей нынешнего Казахстана и Первомайский, Илекский, Мустаевский и 
Ташлинский районы Оренбургской области России. Здесь переходные, среднерусские говоры [4, с. 23].

Языковые особенности наречия уральских (яицких) казаков, содержащие информацию о традициях, их жизненном укладе, относясь к тем русским говорам, в которых выражается дух, душа, природная самобытность простого народа, недостаточно изучены. Анализ социокультурно маркированных языковых единиц - диалектной лексики, характерной для уральского казачества, как особого субэтноса русского народа, позволяет углубить сведения о самобытности, своеобразии языка и культуры этого уникального социального сообщества.

Старообрядцы вели замкнутый, изолированный образ жизни, что позволило им сохранить традиции и устои православия.

Быт казаков-старообрядцев был настолько своеобразен, что во многом отличал их от живущих с ними рядом «никонианцев». Как отмечают исследователи культуры старообрядцев, «ярким примером сочетания патриархальности и самобытности уральского казачества является феномен массового старообрядчества и раскольничества в религиозной культуре» [1]. Укрепление религиозных устоев яицкого казачества было связано с объективными историческими событиями: «избегая преследований и уговоров, раскольники бежали на северо-восток, к Уральским горам и за их пределы» [1, с.75-76], где старались сохранять свою веру, чистоту традиций.

Как известно, казаки-старообрядцы часто относились с предубеждением не только к «никонианам», но и к представителям не своего толка или согласия. Они считали, что иноверца нельзя угощать из своей посуды, из его рук нельзя брать продукты и т.п. Отношение к любой иностранной кухне всегда было насторожённым, нередко староверы в ней пытались отыскать что-либо «бесовское». Круг чужаков для разных категорий старообрядцев отличался: нехристиане, неправославные («нехристи»), нерусские, не казаки («музланы», «бритоусцы»), не старообрядцы, старообрядцы других направлений и прочие [3].

В. И. Даль указывал на неприемлемость многих продуктов (томатов, картофеля, конину, верблюжатину, раков) в системе их питания [2, с. 170].

Современный этнограф А.М. Дубовиков отмечал: «Употребляя в пищу много разнообразных фруктов, овощей и зелени, староверы довольно поздно (к началу XX века) стали употреблять в пищу картофель и помидоры» [3, с. 47].

О крайне резком, негативном отношении старообрядцев - уральских казаков к картофелю свидетельствует следующая иллюстрация из словаря Н. М. Малечи: «Кто будет держать (его) картофель у себя, то не смеет переступать порога моленной, не приму я того человека, всё одно как табашника и бритоусиа» [7, с. 227]. 
Старообрядцы относили чай, чеснок и табак к проклятым травам, не поклонившимся Господу, когда он облетал землю. В начале XX века они начали понемногу пить чай, но лишь из чайника, ибо «самовар не признавали, считали, что в нем есть что-то от дьявола» [8, с. 16]. В речи уральских казаков находим яркие иллюстрации к данным утверждениям: «Самовар - ето сатанинская утроба, в нем огонь - пречиста гибель» [7, с. 18].

Как отмечают современные исследователи, в начале XIX века в войске появился первый самовар. Его вывез из Санкт-Петербурга Л. М. Бородин. В целом он прижился к 40-м годам XIX века, но все-таки были противники таких вещей, малочисленные представители климентовского толка. По учению Климента, в домах запрещалось держать самовары, лампы, так как антихрист воцарился среди людей в виде идола Саморы - самовара [1, с.78].

Казаки-старообрядцы не принимали также табак, считая его чертовым зельем, по их поверьям, дым от табака оскверняет как человека, так и дом.

Н. М. Малеча так комментирует бытование табака в жизни уральских казаков: «Табакур - тот, кто курит табак. С бритоустым и табакуром ни пить, ни есть, ни вкупе богу молиться. Табачище - табачище жрет. Табашник - табачник (кто курит и сеет табак). $V_{-y}$, бритоусиь, табашники и есть с нём не буду - грех» [7, с. 227].

В словаре Н.М. Малечи находим интересные строки, характеризующие отношение старообрядцев к табаку: «Общим приговором соседок этот неистовый овощ (табак) повыдергали с корнем и швырнули в Урал» [5, с. 552]. Запрет на употребление табака неразрывно связан с требованиями к внешнему виду старообрядцев и соблюдением чистоты веры.

Не признавали также казаки кофе: «Кофе - не пьём мы кофию-то, ещё пуще чаю, грех его пить. Хто пьет чай, тот живёт отчаянно, а хто кофь, тот лукав и ков (коварный)» $[5$, с. 260].

Людей, отличающихся «злоупотреблениями», принимавших «грешную» пищу», уральские казаки называли «неистовыми»: Неистовый - неправильный, еретический, не отвечающий требованиям старообрядчества. «Бери, Григорий, образ... - закричал кто-то из зрителей. Не надо, - отвечал ...казак, - может он неистовый» [5, с. 552].

Исследователи казачьей культуры указывают, что в среде уральского казачества была распространена растительная пища, особенно терновник («торн», «торън»), паслен («вороняжка») и другие ягоды [8, с. 16; 3, с. 47].

Автору этих строк, уроженке Первомайского района Оренбургской области, многие детали и лексемы, характеризующие быт и культуру уральских казаков, известны из раннего детства. Многие явления из бытовой сельской жизни имели такие наименования для местных жителей, которые в настоящее время принято относить к диалектной лексике, 
свойственной лишь языку уральских казаков. В памяти хранятся воспоминания, когда все дети лакомились вкусными чернильными ягодами «вороняжки», бывшей в избытке в родных огородах и садах. «Торн» на территории Первомайского района не произрастал, и многие сельчане собирались и дружно выезжали в Уральскую область приграничного Казахстана для сбора ягод. «Торн» - ягода с терпким, вяжущим вкусом, от мороза становилась только вкуснее. Местные жители собирали торн вёдрами, засыпали его сахаром, позже торн обильно выделял сок, хранился он долго, всю зиму, в погребе, подавался к чаю. Позже, когда историческое время стало меняться, не стало возможности запросто ездить в приграничные районы, местные жители стали выращивать в своих садах тернослив, который по традиции называли «торнослив».

Обычными для сельчан были слова «салма» - домашняя лапша, понятное для местных казахов (слово ведь тюрского происхождения), «айран», «каймак», «саман» - кирпичи из глины и соломы, а также «кокурки» - чисто казацкая выпечка и т.д. В Первомайском районе Оренбургской области до сих пор в активной лексике местных жителей используется слово «котлубань» - большой круглой формы ямы в лугах, в которых постоянно держится вода. К географическим названиям можно отнести лексему «чаганак»- залив; или «чаган, чаганак» низкая, кочковатая, поросшая травой заливная местность. Речушка близ районного центра Первомайска носит название Чаган.

Обратимся к традициям уральских казаков. Жизненно важным и значимым для казаков было ношение бороды, что подтверждается тем, как оно именовалось среди уральских казаков. Уральские казаки бороду называют «отечество»; право носить ее отстаивали всеми способами, как истые староверы.

В словаре говоров Н. М. Малечи отмечается: «Отечество - борода. Молодец, отечество блюдёт. Рыжечка просил сохранить отечество. Как тебе не стыдно: из-за бабы поплутной mы отечество снял» [6, с. 96]. В сознании современных носителей языка такое значение лексемы отсутствует: «Отечество - 1. Страна, где родился человек; 2. Место возникновения, происхождения чего-либо (родина)» [10, с. 678].

Примечательна иллюстрация, отраженная в художественной литературе, подчеркивающая эту особенность, - надпись на ордене в форме креста (из петровского серебряного рубля), которым награждал Е. И. Пугачев своих героев: «Награждаю тебя этим крестом, бородой и волей казаиякй. 1774 г.» [4, с. 155].

Бритье бороды, «брадобритие» [7, с. 162], считалось большим грехом у уральских казаков. Бритого называли «скоблёным». «Жена посуды своей «скобленому рылу» не подала бы ни за что, а поколана, что собаку, татарина и нашего брата - «бритоусца» - можно кормить из одной посуды» [7, с. 88]. 
В современном русском литературном языке глагол скоблить сохраняет это значение. Н. М. Малеча указывал: «Скоблено рыло (устар. презрит.) - бреющийся человек; не старовер. Скобленому рылу напиться не дадут, не токо што с ним компанию водить. Борода-ето честь, с своем скобленым рылом не моги в моленну затти [7, с. 88].

Обратимся к требованиям, предъявляемым к внешнему виду женщин. Как известно, обычай требовал, чтобы у замужней женщины волосы были тщательно закрыты головным убором. Обычно замужние женщины расчесывали волосы на пробор, заплетали две косы и укладывали их на голову. Показаться «простоволосой», т.е. с непокрытой головой, считалось позором, грехом. Под платком женщины носили особый чепец - «повойник», который, в отличие от православных, завязывающих повойник узлом, женщины закалывали булавкой. Современные этнографы отмечают обязательность тройного покрытия головы женщины (волосник и два угла платка), как и крест на груди, пояс на рубахе.

В словаре говоров Н. М. Малечи представлены следующие комментарии: «Непокрытый - простоволосая, без платка на голове (по старообрядческим понятиям, выйти при посторонних людях женщине с непокрытой головой - позор, грех. Kydbl-mbl выбегаещь непокрыта? Накройся! Неприкрытый (о замужней женщиине). Всё же оно бы гожей, покрышечку на голову. Грех неприкрыто-то [5, с.557-558].

Анализ семантики лексических единиц, представленных в словаре говоров Н. М. Малечи, позволяет выявить специфику традиционной культуры уральских (яицких) казаков, особенности семейно-бытовой, религиозной обрядности. Обычаи, которые свято соблюдались уральскими (яицкими) казаками, выделяют их среди других старообрядцев. Обратим внимание на выражения, отражающие предрассудки уральских казаковстарообрядцев, зафиксированные в диалекте уральских (яицких) староверов. К таковым относится выражение «святое место», оно обозначало «место, где упал или ударился ктолибо»: «На етим месте, где она ушиблась, - ее (место) прощать надо: святой место. Прости меня, не ты меня нашел, а я тебя... и еще несколько слов (чтоб боль прошла...) [5 , c.422].

Для современных носителей языка такое понимание выражения совершенно не характерно, оно имеет следующее значение: «Святые места - места, связанные с земной жизнью Иисуса Христа и святых».

Речи уральских казаков характерны устойчивые выражения, подчеркивающие чистоту веры. Например, «крепкая вера», означало «строгое соблюдение всех правил старообрядческой веры». Обратимся к иллюстрации, зафиксированной в словаре уральских говоров Н. М. Малечи: - Зайди попить, спроси в Дьяковом, оне больно крепкой веры были, ковиика не дадут, ровно сто лет назад были [5, с. 278]. 
Распространенным в территориальном диалекте было выражение «батенька родимый». Это словосочетание прежде в сравнительном обороте обозначало «чистопородность» уральского казака - «горыныча», или высокую степень проявления какой-нибудь казачьей струнки. - Они мне говорят: «Какой твой сын казак?»-А казак самый настоящий, весь батенька рродимый! Нна! Возьми его! Прям батенька рродимый! Ни дать ни взять! Сыновей обсуждают: пьют. А что им не пить? Чать - батенька родимый (ведь отеи тоже пил). Сыночки, говоришь, таке-сяке, а в кого? Вот он сам-то батенька родимылй [4, с. 106-107].

Высокой частотностью употребления отличается лексема «блюсти», имеющая значения: 1. Соблюдать, хранить обычаи, предписываемые старообрядческими законами. Молодец отечество блюдёт (носит бороду, соблюдая обычай). 2. Сохранять верность мужу (о жене) - А ещуе наказываю тебе, супруга наша, Василиса Потаповна, блюсти себя и содарживать в верности нерушимой (из письма казака кжене) [4, с. 145].

Примечательно выражение: «на благо святых», имеющее значение «на произвол судьбы». Однако в житейском понимании простых уральских казаков выражение не имело современного смыслового компонента «брошен...на произвол судьбы». См. в словаре: - V кого нет детей, так на благо святых (тот оставлен). На благо святых оставили его [4, с. 139].

Диалектизмы, присущие речи уральских казаков, обозначали вполне понятные реалии и события: «Госпожинки, народная календарная c/x дата - дожинки, обжинки (двухнедельный пост перед Успением «госпожи пресвятой Богородицы» 1-15.08). - Первого августа пост - госпожинки. Ездили (в Уральск) на госпожинки еще. Сижу и закусываю калач с огурцами, дело было, помню, в самые госпожинки. А с первого августа, по-старому, госпожинки, две недели этот пост» [4, с. 362].

О суевериях и религиозных представлениях уральских казаков говорит выражение: «зоревая вода»- вода, взятая на заре из колодца или из реки; она, по народным суеверным представлениям, лечит детей от лихорадки и от «глазу». - А ты его зоревой водой, може, его (ребенка) сглазили [4, с. 244].

Активно употреблялось в речи уральцев слово «венец». Обратимся к толкованию лексемы: 1. Венок - Венец из цветов на голову невесте одевали в честь закону русского народа. 2. Религ., уст. - бумажная лента со словами молитвы, возлагаемая на чело покойника. 3. Нимб - Берут церкуль, втыкают (в переносицу лица, изображенного на иконе), отведут (очертят), чего надо - венец там. 4. Созвездие «Северная корона». - Еще есть (на ночном небе) венец. Брать, принимать венец, встать под венец - жениться, выходить замуж. - Василинка венец принимала. Я тода тебе поверю, кода встанем под венец. Тот 
(разведенный) женится, но венец не берет (без церковн. обряда). Отправилась парочка с поездом в церковь принять венцы [4, с. 203].

Непременным атрибутом повседневной жизни уральских казаков-старообрядцев была лестовка. В словаре уральских говоров находим объяснение: «Земляная лестовка - столько земных поклонов, сколько в четках шариков, бусинок (обычно 100). - Старики давали наказание - десять лестовок земляных [5, с. 94].

Известно, что лестовка, принятое в Старообрядческой Церкви приспособление для счета молитв. Впервые употребление лестовки (или вервицы) было установлено в Церкви в IV веке святым Василием Великим в основанных им монастырях. Иноки этих монастырей по любви своей к Богу каждый день совершали по книгам церковным установленное святым Василием молитвенное правило. Для правильного счета молитв Василий Великий ввел в обиход иноков первую лестовку, а точнее, вервицу, - небольшую веревочную петлю, на которой было завязано сто три узла. Лестовка - вспомогательное приспособление для непрестанной молитвы, поэтому благочестивые христиане имели ее с собой всегда, где бы ни находились.

Речь уральских казаков, как бы ни была трудна их жизнь, имела смысловые оттенки доброжелательного характера, выражала легкую иронию или добрый смех. Обратимся к примерам: «Божички» - божки. - Тебе, Никола, два поклона, а тебе, Спас, - один раз, а вы, божички, не прогневайтесь на нас [4, с. 147]. «Боженьки», в междометном восклицанииклятве: ей боженьки! - Стариков очень боялись: не поздороваться - ей боженьки беда! [там же].

Ворожец - колдун, знахарь, гадальщик. - Называть стали его воржецом. Ворожец ворожит. Как же это ты, касатик, узнал, уж не ворожеи ли ты какой? - спросила хозяйка. В Кирсановым хороший ворожец был [4, с. 261].

Богомолец - насмешливое название неудачливого ловца, необрыбившегося». Данильч, лови-что ли? - Нет, товарищ, не дал бог. - Ну, ничего, не все ловцьь, есть и богомольцьь! - Смеется, конечно, тот, кто сам-то попал не в «богомольцыл», а в ловцьь [4, с. 146]. Все примеры характерны народной речи, теплой, меткой и образной.

Таким образом, исследование живого народного языка позволяет открыть новые грани многовековой жизни уральского казачества.

\section{Список литературы}


1. Гурская Н. В. Патриархальные обычаи как неотъемлемый фактор складывания самобытных культурных элементов Уральского (Яицкого) казачества // Вестник Челябинского государственного университета. 2010. № 16. С. 74-82.

2. Даль В.И. Уральский казак // Оренбургский край в произведениях писателя. Оренбург: Оренбургское книжное изд-во, 2001. 416 с.

3. Дубовиков А. М. Повседневная культура Уральского казачества (XVI-XIX вв.) // Вестник Оренбургского государственного университета. 2008. № 10 (92). С. 44-49.

4. Малеча Н. М. Словарь говоров уральских (яицких) казаков: в 4 т. Оренбург: Оренбургское книжное изд-во, 2002-2003. Т. 1. 496 с.

5. Малеча Н. М. Словарь говоров уральских (яицких) казаков: в 4 т. Оренбург: Оренбургское книжное изд-во, 2002-2003. Т. 2. 592 с.

6. Малеча Н. М. Словарь говоров уральских (яицких) казаков: в 4 т. Оренбург: Оренбургское книжное изд-во, 2002-2003. Т. 3. 568 с.

7. Малеча Н. М. Словарь говоров уральских (яицких) казаков: в 4 т. Оренбург: Оренбургское книжное изд-во, 2002-2003. Т. 4. 536 с.

8. Масянов Л.Л. Гибель Уральского казачьего войска. Нью-Йорк: Всеславянское изд-во, 1963. $166 \mathrm{c}$.

9. Пирманова Н.И. От языка уральских (яицких) казаков - к духовной вере и культуре Филологические науки. Вопросы теории и практики (входит в перечень ВАК). Тамбов: Грамота, 2014. № 10. Ч. 2. С. 139-142. ISSN 1997-2911.

10. Словарь русского языка: в 4 т. / А.Н. СССР, ин-т рус. яз.; под ред. А. П. Евгеньевой. 2-е изд., испр. 1981-1984. Т. 1. 696 с.

\section{Рецензенты:}

Кузнецова Н.Н., д.ф.н., доцент, профессор кафедры современного русского языка, риторики и культуры речи филологического факультета Оренбургского государственного педагогического университета, г. Оренбург;

Прокофьева В.Ю., д.ф.н., профессор, профессор кафедры современного русского языка, риторики и культуры речи филологического факультета Оренбургского государственного педагогического университета, г. Оренбург. 